\title{
INTRA-OCULAR HYDATID CYST
}

\author{
BY \\ M. M. ARORA, R. P. DHANDA, A. G. BHAGWAT, AND V. K. KALEVAR \\ From the Departments of Pathology and Ophthalmology, M.G.M. Medical College and M.Y. Hospital, \\ Indore, India
}

INTRA-OCULAR parasites have been referred to as ophthalmological curiosities (Costi, 1934; Duke-Elder, 1940). Larvae of Filaria loa, Filaria bancrofti, Dracunculus medinensis, and Taenia solium have been observed only infrequently inside the eyeball. Taenia echinococcus infestation is by far the rarest of the parasitic diseases of the eye, only eleven cases having so far been reported in the literature. Three of these cases, those reported by Gescheidt (1833), Scholtz (1906), and Wood (1906), have been considered by Duke-Elder (1940) and Sverdlick (1961) to be lacking authenticity. Scholtz (1906) could not carry out any histopathological or cytological studies to confirm his clinical diagnosis since the disease had occurred in the only eye in his case.

The present case adds one more to this small list and is probably the first to be reported from India.

\section{Case Report}

A 16-year-old male Hindu vegetarian patient first visited the M.Y. Hospital in March, 1959, and was examined by one of us (R.P.D.). At that time his complaints were of defective vision in the left eye and dull headache off and on for the last few months.

Examination.-A round smooth mass was seen behind the lens, occupying the inner half of the vitreous chamber. The fundus glow and other fundus details could be studied through the remaining clear portion of the vitreous and appeared to be normal.

Diagnosis.-A vitreous cyst of parasitic origin (Taenia echinococcus).

Surgery was advised and a trans-scleral aspiration biopsy was planned, but to this the patient did not agree and he left the hospital against medical advice.

Progress.-In January, 1961, he developed a severe left-sided headache and pain in the left eyeball and had to return for treatment. On inquiry he informed us that about 20 days previously needling had been done at Jubbalpore for cataract in the same eye.

Examination.-There was no perception or projection of light in any direction and the anterior chamber was shallow but no underlying lesions could be visualized on account of a secondary cataract.

Operations.-A curette evacuation was performed on January 16, 1961, to clear up the pupillary area and to study the posterior segment of the eyeball. After the operation the anterior chamber failed to form and the fundus glow could not be visualized on account of a white glistening growth filling the entire vitreous chamber.

Pain in the eye and raised intra-ocular pressure persisted and a year later, on January 24, 1962, the left eyeball was enucleated to relieve the pain and headache. 

free.

Result.-Post-operative convalescence was uneventful and the patient became entirely symptom-

Pathological Report.-The eyeball was cut into two equal halves for study. A cystic mass was seen to occupy the entire posterior segment of the eyeball. The outer coat of this mass could easily be separated from the retina and was smooth and white like the outer surface of a hard-boiled egg. Inside this big cyst were seen numerous small daughter cysts ranging in diameter from 1 to $2.5 \mathrm{~mm}$., many of which were filled with clear watery fluid (Fig. 1).

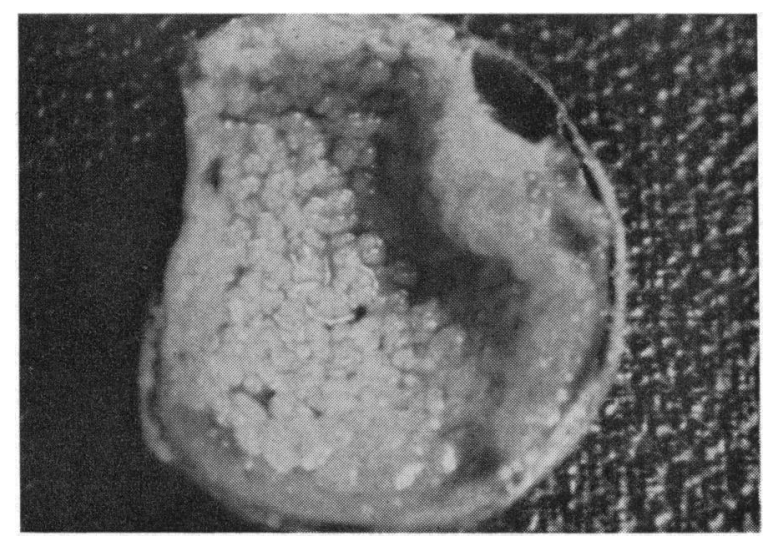

Fig. 1.-Eyeball cut open to show entire posterior segment filled by hydatid cysts.

Microscopic Examination.-The cyst wall was formed by a hyalinized, onion-skin-like, laminated membrane. Only the ectocyst was identifiable in the histological section. The inner germinal layer and the embryo were not visible in any of the cysts. At many places, disorganization of the retinal layers, subretinal haemorrhages, and inflammatory changes in the retina and choroid were seen (Fig. 2).

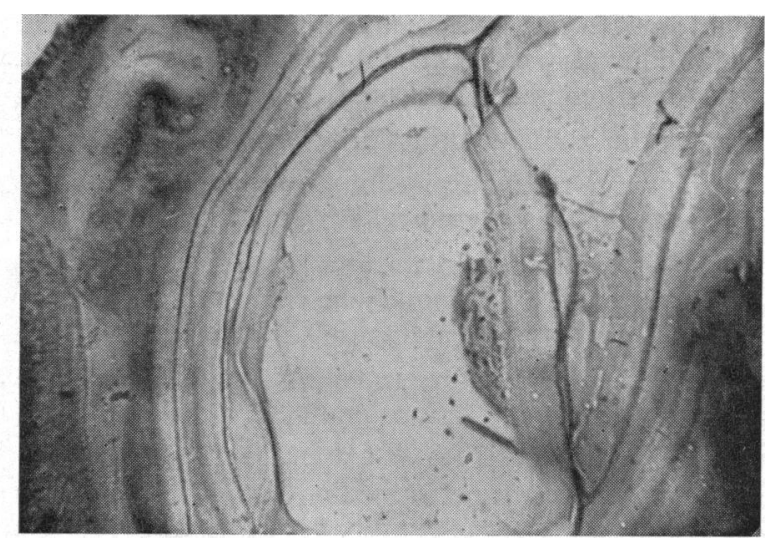

FIG. 2.-Laminated cell wall (ectocyst) with disorganized retinal layers on one side. Haematoxylin and eosin. $\times 100$.

Fluid from the cyst was examined for hooklets but was negative. A histopathological diagnosis was made of an intra-ocular hydatid cyst with secondary inflammatory changes in the choroid and retina. 


\section{Comment}

It is well known that the Taenia echinococcus embryo after burrowing through the intestinal mucosa enters the portal vein radicles, from whence it passes to the liver, lungs, and other organs of the body via the blood stream. It rarely enters the eye, although Dévé (1921) successfully demonstrated the development of a hydatid cyst experimentally in the eyes of rats by injection of scolices into the carotid artery. Demaría (1919) was also able to produce intra-ocular lesions in a rabbit by injecting into its eye fluid obtained from a hydatid cyst in a sheep.

No age predilection of intra-ocular hydatid cysts has been observed although the condition has mostly been found in younger patients in other sites.

Both sexes are known to be equally affected by Taenia echinococcus infestation of the other organs, but the majority of reported cases of intra-ocular hydatid cysts have occurred in males.

The vitreous chamber and subretinal spaces are the two common sites, and in our case the cyst filled the entire posterior segment, thus resembling cases reported by Demaría (1919), Griffith (1887), and Litricin (1953).

Since intra-ocular hydatid cysts are located in a rigid and limited space, the cyst fluid at the time of pathological studies is usually sterile; in fact hooklets have been demonstrated in the cyst fluid only once (Werner, 1903).

In the present case the cyst wall was composed of only a laminated ectocyst. The endocyst and the brood capsule undergo necrosis because of the increased intracystic tension and are therefore not seen. Two previous reports record similar observations (Griffith, 1887; Wood, 1906).

Although a Taenia echinococcus cyst inside the eyeball is rare, the possibility of such a lesion should always be considered in the differential diagnosis of retrolental cysts.

We are grateful to the Superintendent, M.Y. Hospital, Indore, and the Dean, M.G.M. Medical College, Indore, for permission to publish this case, and to Mr. V. S. Godbole for technical assistance.

\section{REFERENCES}

Costı, C. (1934). "Libro-atlas de biomicroscopica del cuerpo vitreo", p. 164. Soc. oftal. hisp.-amer. (cited by Duke-Elder, p. 3432).

DukE-ELDER, S. (1940). "Text-book of Ophthalmology", vol. 3, pp. 3432, 3445. Kimpton, London.

DÉvê, F. (1921). Ann. Oculist. (Paris), 158, 721.

Demarta, B. E. (1919). Arch. Oftal. hisp.-amer., 19, 461.

De Lieto Vollaro, A. (1930). Boll. Ocul., 9, 1345.

GeSCHEIDT, V. (1833). "Die Entozoen des Auges", Z. Ophthal., 3, 405, ed. A. von Ammon, Dresden.

GRIFFITH, A. H. (1887). Trans. ophthal. Soc. U.K., 17, 220.

LITRICIN, O. (1953). A.M.A. Arch. Ophthal., 50, 506.

RAPAPORT, M., MirRès, A., and CicolInI, J. (1957). Rev. As. med. Argent., 71, 189.

SVERDLICK, J. (1961). Amer. J. Ophthal., 52, 981.

ScHOLTz, K. (1906). Arch. Augenheilk., 54, 170.

WERNER, L. (1903). Trans. ophthal. Soc. U.K., 23, 193.

WoOD, D. J. (1906). Ibid., 26, 152. 